\title{
The potential renal toxicity of silver nanoparticles after repeated oral exposure and its underlying mechanisms
}

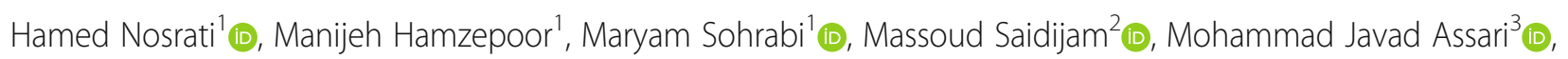
Nooshin Shabab², Zahra Gholami Mahmoudian ${ }^{1}$ and Zohreh Alizadeh ${ }^{4, *^{*}}$

\begin{abstract}
Background: Silver nanoparticles (AgNPs) can accumulate in various organs after oral exposure. The main objective of the current study is to evaluate the renal toxicity induced by AgNPs after repeated oral exposure and to determine the relevant molecular mechanisms.

Methods: In this study, 40 male Wistar rats were treated with solutions containing 30, 125, 300, and $700 \mathrm{mg} / \mathrm{kg}$ of AgNPs. After 28 days of exposure, histopathological changes were assessed using hematoxylin-eosin (H\&E), Masson's trichrome, and periodic acid-Schiff (PAS) staining. Apoptosis was quantified by TUNEL and immunohistochemistry of caspase-3, and the level of expression of the mRNAs of growth factors was determined using RT-PCR.

Results: Histopathologic examination revealed degenerative changes in the glomeruli, loss of tubular architecture, loss of brush border, and interrupted tubular basal laminae. These changes were more noticeable in groups treated with 30 and $125 \mathrm{mg} / \mathrm{kg}$. The collagen intensity increased in the group treated with $30 \mathrm{mg} / \mathrm{kg}$ in both the cortex and the medulla. Apoptosis was much more evident in middle-dose groups (i.e., 125 and $300 \mathrm{mg} / \mathrm{kg}$ ). The results of RT-PCR indicated that BCl-2 and Bax mRNAs upregulated in the treated groups $(p<0.05)$. Moreover, the data related to EGF, TNF- $a$, and TGF- $\beta 1$ revealed that AgNPs induced significant changes in gene expression in the groups treated with 30 and $700 \mathrm{mg} / \mathrm{kg}$ compared to the control group.
\end{abstract}

Conclusion: Our observations showed that AgNPs played a critical role in in vivo renal toxicity.

Keywords: Silver nanoparticles, Toxicity, Apoptosis, Kidney

\section{Introduction}

Advances in nanotechnology have greatly enhanced its potential usage in domestic, industrial, and biomedical applications [1,2]. Due to their unique physicochemical and biological properties, AgNPs are widely used, indicated by a significant increase in the number of products that contain AgNPs from about 30 in 2006 to more than

\footnotetext{
* Correspondence: alizadeh@umsha.ac.ir; alizadeh.zohreh@gmail.com ${ }^{4}$ Endometrium and Endometriosis Research Center, Hamadan University of Medical Sciences, Hamadan, Iran

${ }^{5}$ Department of Anatomical Sciences, Hamadan University of Medical Sciences, Shahid Fahmideh Ave., P.O. Box. 65178-518, Hamadan, Iran Full list of author information is available at the end of the article
}

435 in 2015 [3, 4]. AgNPs have also been widely used in biomedical applications, such as wound healing, drug delivery systems, catheter modification, dental applications, and bone tissue engineering [5]. According to PubMed statistics, the number of studies on "silver nanoparticles" has also increased over the last decade (i.e., from $896 \mathrm{pa}$ pers in 2010 to 2529 in 2020). Because of their small size, AgNPs can enter the human body through ingestion [6], inhalation [7], and skin contact [8]. Kidneys, lungs, nervous system, and liver are organs prone to the accumulation of AgNPs [7, 9]. Induction of inflammatory and cytotoxicity effects by AgNPs in different cells

C C The Author(s). 2021 Open Access This article is licensed under a Creative Commons Attribution 4.0 International License, which permits use, sharing, adaptation, distribution and reproduction in any medium or format, as long as you give appropriate credit to the original author(s) and the source, provide a link to the Creative Commons licence, and indicate if changes were made. The images or other third party material in this article are included in the article's Creative Commons licence, unless indicated otherwise in a credit line to the material. If material is not included in the article's Creative Commons licence and your intended use is not permitted by statutory regulation or exceeds the permitted use, you will need to obtain permission directly from the copyright holder. To view a copy of this licence, visit http://creativecommons.org/licenses/by/4.0/ The Creative Commons Public Domain Dedication waiver (http://creativecommons.org/publicdomain/zero/1.0/) applies to the data made available in this article, unless otherwise stated in a credit line to the data. 
and tissues has been reported in studies performed in vitro and in vivo [9-11]. The most well-known mechanism of AgNPs cytotoxicity involves the induction of oxidative stress, caused by the generation of intracellular reactive oxygen species (ROS), glutathione depletion, a decrease in superoxide dismutase enzyme activity, and an increase in lipid peroxidation [12]. It has been reported that the oxidative stress induced by AgNPs is independent of the toxicity of $\mathrm{Ag}^{+}$ions generated within the cells [13].

Decreased renal function due to the apoptosis of intrinsic renal cell populations is a characteristic feature of renal disorders, caused by different etiologies, such as toxins. Enhanced apoptosis has been shown to lead to glomerulosclerosis and tubular atrophy [14].

The induction or suppression of apoptosis are influenced by a large number of growth factors. For instance, the epidermal growth factor (EGF) has an in vitro protective effect on renal cells against apoptotic stimuli, such as serum deprivation [15]. In contrast, it has been reported that the transforming growth factor- $\beta 1$ (TGF$\beta 1$ ) and the tumor necrosis factor- $\alpha$ (TNF- $\alpha$ ) induce apoptosis in renal fibroblasts, tubular epithelial cells [16, 17], and glomerular epithelial cells [18].

The main objective of the current study is to evaluate the extent of renal toxicity induced by different doses of AgNPs after 28 days of oral exposure and to determine the relevant molecular mechanisms. To do so, we assess the effects of AgNPs on the kidney in terms of (1) the reno-somatic index, (2) serum creatinine and blood urea nitrogen levels, (3) histological changes, and (4) changes in the expression of apoptosis-associated and growth factors genes.

\section{Material and methods \\ Animals}

In a controlled environment of an animal house (a temperature of $21 \pm 2{ }^{\circ} \mathrm{C}$, a humidity of $50 \pm 15 \%$, and a light/dark cycle of $12 \mathrm{~h}$ ), forty 10 to 12 -week old adult male Wistar rats (180-200 g) were housed during the experimental period ( 28 days) with access to water and food ad libitum. The animal bodyweights were recorded before and after the treatment with AgNPs. The bodyweight gain was calculated by subtracting the initial body weight from the final bodyweight [9]. The reno-somatic index (RSI) was calculated according to the following standard formula:

$$
\text { RSI }=\text { Kidney weight }(\mathrm{g}) / \text { bodyweight }(\mathrm{g}) \times 100
$$

\section{Silver nanoparticles}

The suspension of the AgNPs powder (US Research Nanomaterials Inc., Houston, TX, USA, Stock\#: US1008) was prepared in accordance with the procedure described in our previous study [19]. Briefly, different concentrations of AgNPs (i.e., 30, 125, 300, and $700 \mathrm{mg}$ ) were dispersed in deionized water by vortexing, followed by sonication for $10 \mathrm{~min}$. The particle-size distribution of AgNPs was measured using the dynamic lightscattering (DLS) technique by a Malvern Zetasizer (Nano ZS ZEN-3600, UK). Moreover, a transmission electron microscope (TEM) (Philips-EM 208) was used to determine the size and shape of the nanoparticles.

\section{The experimental design}

The animals were randomly divided into four treatment groups and a control group ( $n=8$ for each group). Rats in the first four groups were administered $30,125,300$, and $700 \mathrm{mg} / \mathrm{kg}$ of AgNPs suspension orally for 28 days, respectively. Equal volumes of deionized water were administered to the control group [11]. The animals were sacrificed $24 \mathrm{~h}$ after the last administration to harvest and weigh their kidneys. The left kidney of each rat was frozen at $-80^{\circ} \mathrm{C}$ for molecular studies, while the right kidney was immersed in a 10\% neutral buffered formalin solution for further histopathological investigations.

\section{Determination of blood urea nitrogen (BUN) and creatinine}

Blood samples were collected through a cardiac puncture and allowed to clot for $45 \mathrm{~min}$ at room temperature. The serum was separated by centrifugation at $1500 \mathrm{~g}$ for $10 \mathrm{~min}$. BUN and creatinine were measured using an AutoAnalyzer (Hitachi 7180, Hitachi, Japan) and standard assay kits.

\section{The histological study}

The fixed tissues were processed routinely using the standard technique, followed by being embedded in paraffin, and $5 \mu \mathrm{m}$-thick sections were prepared for hematoxylin and eosin (H\&E) staining. Special staining techniques, Masson's trichrome, and periodic acid-Schiff (PAS) were performed to evaluate the collagen deposition changes, brush border, and tubular basal lamina, respectively. All the images were acquired by a Moticam 2000 camera (Kowloon, Hong Kong) attached to a Nikon Eclipse E800 research transmitted light microscope (Melville, New York, USA). The Motic Images 2.0 software was used for H\&E and PAS stained sections and ImageJ (version 1.52a) was used for Masson's trichrome stained slides to evaluate the variations in the histomorphology of the groups.

\section{Terminal deoxynucleotidyl transferase dUTP nick end labeling (TUNEL) assay}

A TUNEL assay kit (Promega Co., Madison, WI, USA, CAT. \#G7130) was used to assess cell apoptosis in renal 
tissues according to the instructions provided by the manufacturer. Paraffin-embedded tissue sections were deparaffinized, rehydrated, and permeabilized with a proteinase $\mathrm{K}$ solution for $30 \mathrm{~min}$. Tissue sections were then incubated with biotinylated nucleotide mix, recombinant terminal deoxynu-cleotidyl transferase $(\mathrm{TdT})$, and an equilibration buffer for $1 \mathrm{~h}$ at $37^{\circ} \mathrm{C}$. The sections were incubated in a converter-POD solution for $30 \mathrm{~min}$ after rinsing with PBS. Dehydration was performed using graded ethanol. The sections were covered with the mounting medium (Scytek Laboratories, Logan, UT, USA) and counterstained with Mayer's Hematoxylin Solution. During the tailing reactions, $\mathrm{TdT}$ was eliminated as a negative staining control.

The average number of apoptotic cells was determined by counting TUNEL-positive cells in five neighboring fields at a magnification of $\times 400$, dividing the total by five, and expressing the result as a percentage.

\section{Immunohistochemistry}

Changes in the distribution and expression of the caspase- 3 protein in renal tissues were evaluated by immunohistochemistry in the prepared kidney sections. Briefly, tissue sections with a thickness of $4 \mu \mathrm{m}$ were sequentially deparaffinized, rehydrated, and submitted for antigen retrieval. The sections were incubated overnight at $4{ }^{\circ} \mathrm{C}$ with the rabbit anti caspase- 3 antibody (ab13847, 1:200) diluted in PBS. After washing, the secondary antibody bond to the biotin (Detection Kit Goat Anti-Rabbit HRP (IgG) (Ab6721) Abcam) was applied for $15 \mathrm{~min}$, and then streptavidin-horseradish peroxidase (HRP) was added, followed by incubation in a moisture box at room temperature for $15 \mathrm{~min}$. The results were developed using $\mathrm{DAB}$, and the sections were mounted and observed under a light microscope. Immuno-positive cells were counted and expressed as percentage.

\section{RNA extraction and quantitative realtime polymerase chain reaction}

Total RNA was extracted from the renal tissues of the rats using the TRIzol $^{\circ}$ reagent (Invitrogen), according to the protocol provided by the manufacturer. The RNA concentration was determined using an Epoch Microplate Spectrophotometer (Biotek, USA). The extracted RNA was reverse transcribed into single-strand cDNA using the RevertAid ${ }^{\text {ma }}$ first-strand cDNA synthesis kit (Thermo Scientific) according to the manufacturer's instructions. The transcription process included incubation of the reaction mixture at $20^{\circ} \mathrm{C}$ for $30 \mathrm{~s}$, followed by $5 \mathrm{~min}$ at $44^{\circ} \mathrm{C}, 30 \mathrm{~s}$ at $55^{\circ} \mathrm{C}$, and $5 \mathrm{~min}$ at $95^{\circ} \mathrm{C}$. The cDNA was stored at $-80^{\circ} \mathrm{C}$ until further use for PCR.

Quantitative real-time PCR analyses were carried out using the SYBR premix Ex Taq 2 kit (Takara) in a final volume of $25 \mu \mathrm{l}$ with $10 \mathrm{pmol}$ of each primer by the
CFX96 real-time PCR detection system (BioRad, USA). Each assay was run in the triplicate manner with each set of primers. The sequences of primers, accession number, and primer-specific annealing temperature are presented in Table 1.

Cycle threshold $(\mathrm{Ct})$ values were obtained using the auto $\mathrm{Ct}$ function. The mean $\mathrm{Ct}$ value was determined after efficiency correction, and it was then normalized to the reference gene (18S rRNA) using delta $(\Delta) \mathrm{Ct}$. The relative expression changes were determined using the $2^{-\Delta \Delta C t}$ method [20].

\section{Statistical analysis}

The statistical analysis was performed using SPSS 16.0 (IBM, USA), and the data were presented as mean \pm standard deviation (SD). The statistically-significant changes were determined using a one-way analysis of variance (one-way ANOVA) and the Tukey test. Pvalues less than $0.05 \quad(p<0.05)$ were considered statistically-significant changes. The Pearson's correlation analysis was used to determine the correlation values $(r)$ between the parameters.

\section{Ethical statement}

The above-mentioned treatment/sampling protocols were approved by the Ethics Committee of Hamadan University of Medical Sciences (ethical code: IR.UMSHA.REC.1394.553). Moreover, all the methods were carried out in accordance with the relevant guidelines and regulations. The study was carried out in compliance with the ARRIVE guidelines.

\section{Results}

Nanoparticles characterization in solution

The AgNPs suspension was subjected to dynamic light scattering (DLS) analysis to determine the diameter of the nanoparticles. It exhibited a hydrodynamic diameter peak with an average size of approximately $250 \mathrm{~nm}$. The TEM images of AgNPs showed that the majority were spherically-shaped with smooth surfaces (Fig. 1).

\section{Body and organ weight}

Table 2 shows the results of bodyweight gain and the reno-somatic index. There were no significant doserelated changes in the bodyweight gains of the rats. In addition, no significant changes in the reno-somatic index were observed in the treated rats, except for an increase $(P<0.05)$ in the index of the right kidney for the group receiving $30 \mathrm{mg} / \mathrm{kg}$.

\section{Blood urea nitrogen (BUN) and creatinine}

In this study, kidney function was evaluated based on the serum levels of BUN and creatinine. However, these parameters showed no statistically-significant differences 
Table 1 Features of the primers of the studied genes

\begin{tabular}{|c|c|c|c|}
\hline Gene & Accession number & Primer sequence & Annealing temperature \\
\hline Bax & NM_017059 & $\begin{array}{l}\text { F: GAGACACCTGAGCTGACCTTG } \\
\text { R:CCTGCCACACGGAAGAAGACCTC }\end{array}$ & 55 \\
\hline $\mathrm{BCl}-2$ & NM_016993 & $\begin{array}{l}\text { F: CGGGAGAACAGGGTATGATA } \\
\text { R: TCAGGCTGGAAGGAGAAGATGC }\end{array}$ & 54 \\
\hline EGF & NM_012842 & $\begin{array}{l}\text { F: AACTGTGTCATTCCAGGATC } \\
\text { R:CGAGTCCTGTAGGATCGCCAT }\end{array}$ & 55 \\
\hline TGF- $\beta 1$ & NM_021578.2 & $\begin{array}{l}\text { F: ATTCAAGTCAACTGTGGAGCAAC } \\
\text { R: CGAAAGCCCTGTATTCCGTCT }\end{array}$ & 57 \\
\hline TNF-a & NM_012675.3 & $\begin{array}{l}\text { F: TGTTCATCCGTTCTCTACCCA } \\
\text { R: CACTACTTCAGCGTCTCGT }\end{array}$ & 55 \\
\hline 18SrRna & NM_031144 & $\begin{array}{l}\text { F:CGGAAGACTCACACCTTGA } \\
\text { R:GTCCTCAGTGTAGCCCAAGA }\end{array}$ & 53 \\
\hline
\end{tabular}

between experimental and control groups after 28 days of exposure to AgNPs (Table 2).

\section{Histological evaluation H\&E-stained sections}

Tissue sections from the control group showed a typical histological structure in different parts, such as renal corpuscles, proximal and distal convoluted tubules, and the interstitial tissue. Sections from groups treated with AgNPs showed many forms of glomerular, tubular, and interstitial changes (Fig. 2).

Glomerular Alterations: The cortex showed partial destruction of renal corpuscles with collapsed glomerular tufts, widening of the Bowman's space, and necrosis. The mean glomerular diameter was also measured. This parameter reduced significantly in the group treated with $125 \mathrm{mg} / \mathrm{kg}$ compared to the control group $(p<0.05)$.

Tubular Alterations: In groups treated with AgNPs, loss of tubular architecture was observed, and the epithelial lining of the tubules in the cortex showed cytoplasmic necrosis and vacuolation. The luminar site of several cortical tubules displayed dense acidophilic

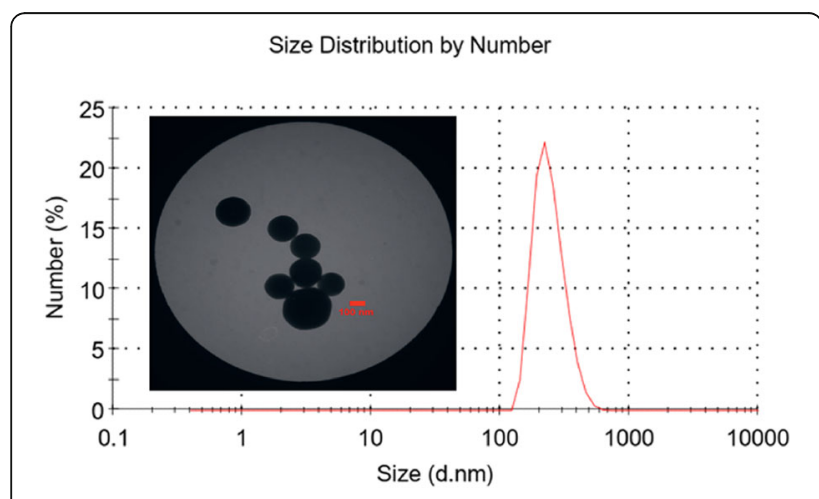

Fig. 1 TEM micrograph and particle size distribution of AgNPs hyaline casts. Moreover, shedding and desquamation of the lining epithelium were observed more prominently in the proximal tubules of the groups treated with 30 and $125 \mathrm{mg} / \mathrm{kg}$.

Interstitial Tissue Alterations: The most significant histological changes in the renal interstitial tissue, including infiltration of inflammatory cells and congestion, were observed in rats exposed to 125, 300, and $700 \mathrm{mg} / \mathrm{kg}$ of AgNPs (Fig. 2).

\section{PAS-stained sections}

Regarding PAS staining, the disruption of the brush border and the basement membrane integrity were observed in the renal tubules of the groups treated with 30 and $125 \mathrm{mg} / \mathrm{kg}$ of AgNPs compared to the control group. The cortical tubules from groups treated with 300 and $700 \mathrm{mg} / \mathrm{kg}$ showed a protected brush border and continuous basal lamina (Fig. 3).

\section{Masson's trichrome-stained sections}

Masson's trichrome quantified the blue intensity (representing collagen deposition) within the renal tissue. The blue intensity increased in the groups treated with 30 $(p<0.05)$ and $125(p>0.05) \mathrm{mg} / \mathrm{kg}$ in both the cortex and the medulla. It was shown that in the groups treated with 300 and $700 \mathrm{mg} / \mathrm{kg}$, the collagen content was almost similar in normal renal tissues (Fig. 4). PAS staining confirmed the results of the Masson's trichrome staining for collagen sedimentation.

\section{TUNEL assay}

To assess the effects of treatment with AgNPs on renal tubular cell apoptosis, renal tissue sections were examined by performing TUNEL staining. As illustrated in Fig. 5, the number of TUNEL-positive tubular cells increased in the groups treated with $125(p>0.05)$ and 300 $(P<0.05) \mathrm{mg} / \mathrm{kg}$ compared to the control, 30, and 700 $\mathrm{mg} / \mathrm{kg}$ groups. 
Table 2 Bodyweight gain, the reno-somatic index, and the serum levels of BUN and creatinine after 28-day oral administration of AgNPs (mean \pm S.D.)

\begin{tabular}{llllll}
\hline Groups & $\begin{array}{l}\text { Body weight gain } \\
(\mathbf{g})\end{array}$ & $\begin{array}{l}\text { Reno-somatic index (left kidney) } \\
(\%)\end{array}$ & $\begin{array}{l}\text { Reno-somatic index (right kidney) } \\
(\%)\end{array}$ & $\begin{array}{l}\text { BUN } \\
\text { dL) }\end{array}$ & $\begin{array}{l}\text { Creatinine (mg/ } \\
\text { dL) }\end{array}$ \\
\hline Control & $72.72 \pm 19.50$ & $0.37 \pm 0.05$ & $0.35 \pm .04$ & $67.60 \pm 4.72$ & $0.70 \pm 0.07$ \\
$30 \mathrm{mg} / \mathrm{kg}$ & $61.02 \pm 8.045$ & $0.42 \pm 0.02$ & $0.43 \pm 0.04^{*}$ & $62.25 \pm 3.20$ & $0.70 \pm 0.08$ \\
$125 \mathrm{mg} /$ & $76.63 \pm 18.57$ & $0.37 \pm 0.03$ & $0.36 \pm 0.04$ & $59.50 \pm 1.73$ & $0.68 \pm 0.05$ \\
$\mathrm{~kg}$ & & & & $62.50 \pm 5.00$ & $0.78 \pm 0.05$ \\
$300 \mathrm{mg} /$ & $64.52 \pm 7.98$ & $0.35 \pm 0.03$ & $0.36 \pm 0.02$ & & \\
$\mathrm{~kg}$ & & & $0.37 \pm 0.02$ & $62.50 \pm 3.00$ & $0.60 \pm 0.08$ \\
$700 \mathrm{mg} /$ & $67.05 \pm 2.29$ & $0.36 \pm 0.03$ & & & \\
$\mathrm{~kg}$ & & & & \\
\hline
\end{tabular}

*Significant difference compared to the control, $p<0.05$

\section{Immunohistochemistry}

The percentages of caspase-3 positive cells were obtained in the stained slides. The results are shown in Fig. 6, indicating a significant difference in the expression of caspase- 3 between the groups treated with 125 , 300 , and $700 \mathrm{mg} / \mathrm{kg}$ and the control group $(P<0.05)$.

\section{Expression of apoptosis-associated genes}

As illustrated in Fig. 7, Bax mRNA concentration increased in the groups treated with 30 and $700 \mathrm{mg} / \mathrm{kg}$ compared to the controls group. While the expression of this gene increased in groups treated with 125 and 300 $\mathrm{mg} / \mathrm{kg}$, this increase was not statistically significant $(P<$ 0.05). The expression of Bax in groups treated with 30 , 125,300 , and $700 \mathrm{mg} / \mathrm{kg}$ was $4.47,1.91,1.69$, and 3.96 times that of the control group, respectively.
Bcl-2 mRNA concentration increased significantly in groups treated with 30,300 , and $700 \mathrm{mg} / \mathrm{kg}$ compared to the control group $(P<0.05)$ (Fig. 7). The average level of Bcl-2 gene expression in groups treated with 30, 125, 300 , and $700 \mathrm{mg} / \mathrm{kg}$ increased by $6.37,2.16,4.42$, and 11.69 folds, respectively.

The Bax/Bcl-2 ratios of the mRNA levels are shown in Fig. 7. These ratios significantly increased in the groups treated with 300 and $700 \mathrm{mg} / \mathrm{kg}$ compared to the control group.

\section{Expression of growth factors}

Analysis of the expression of growth factors revealed the upregulation of the EGF mRNA concentration in groups treated with 30,125 , and $700 \mathrm{mg} / \mathrm{kg}$ compared to the control group (Fig. 8). Moreover, TNF- $\alpha$ mRNA expression increased in the groups treated with $30,125,300$,

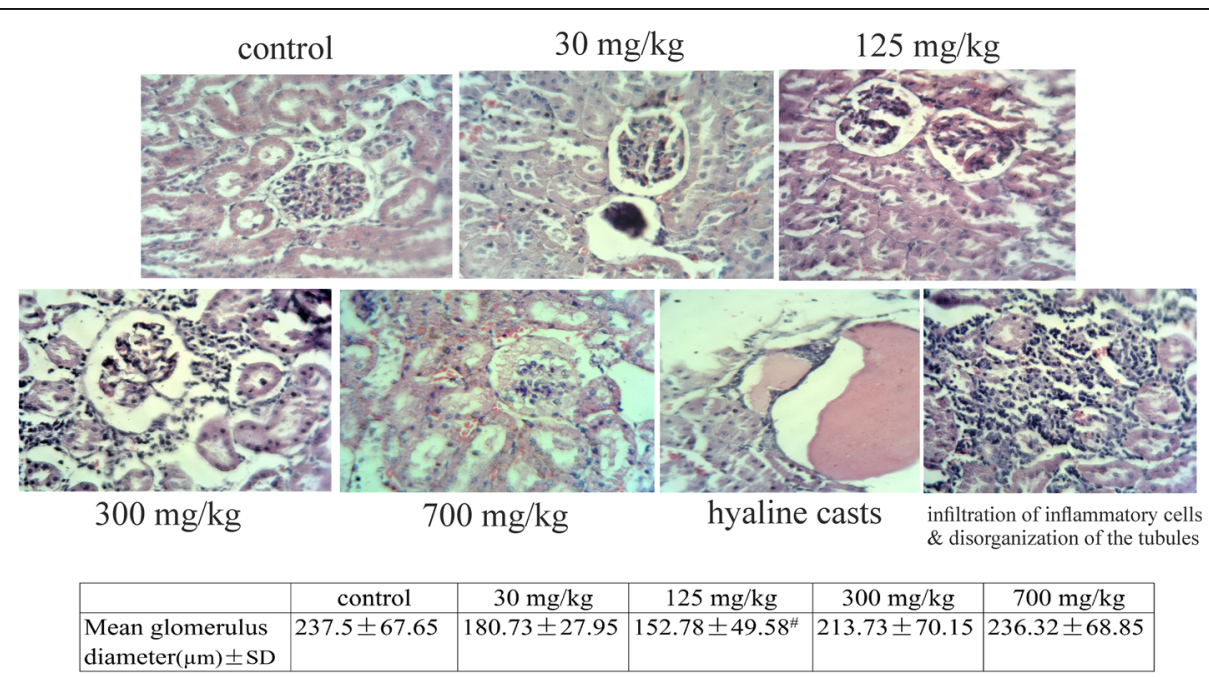

Fig. 2 Light micrographs of rat kidney sections (H\&E stain, $\times 400$ ). The renal cortex shows a normal architecture in the control group. Groups treated with 30,125, and $300 \mathrm{mg} / \mathrm{kg}$ show marked degenerative changes in the glomeruli, showing necrosis with loss of glomerular tufts and wide Bowman's space. The group treated with $700 \mathrm{mg} / \mathrm{kg}$ shows swelled renal glomerulus. Hyaline casts in renal tubule are observed in the group treated with $125 \mathrm{mg} / \mathrm{kg}$. Congestion of the capillary loops, infiltration of inflammatory cells, and disorganization of the tubules are seen in the groups treated with AgNPs. The effects of various concentrations of AgNPs on the diameter of the glomeruli are presented and compared to the control group. $\# P<0.001$ 


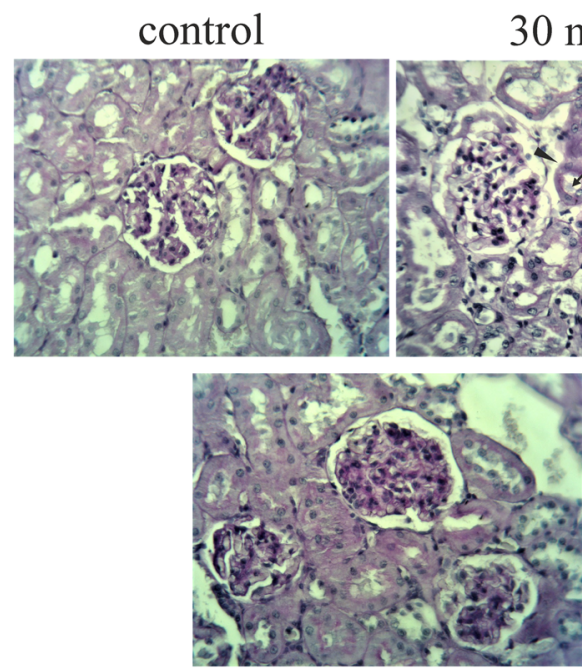

$300 \mathrm{mg} / \mathrm{kg}$

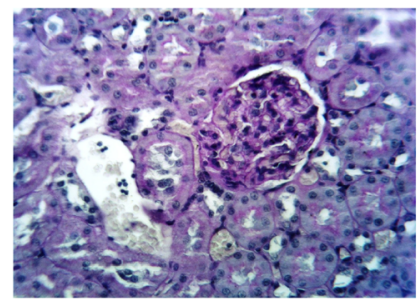

$700 \mathrm{mg} / \mathrm{kg}$

Fig. 3 Periodic acid-Schiff (PAS) staining of kidney sections after 28 days of oral exposure to AgNPs (original magnification $\times 400$ ). The disruption of the brush border (arrows) and the basement membrane integrity (arrowheads) were observed in the renal tubules of the groups treated with 30 and $125 \mathrm{mg} / \mathrm{kg}$ of AgNPs

and $700 \mathrm{mg} / \mathrm{kg}$. The results obtained from evaluating TGF- $\beta 1$ mRNA expression showed no statisticallysignificant differences between the control group and the experimental groups despite the fact that the increased expression of this gene was seen in groups treated with 30 and $700 \mathrm{mg} / \mathrm{kg}(P>0.05)$.
Correlation between apoptosis and the expression of genes influencing cell death

A significant positive correlation was observed between the mRNA levels of Bax and Bcl-2 $(\mathrm{r}=0.850, P=$ 0.0001). The caspase-3 expression was correlated with the ratio of $\Delta \mathrm{Ct} \mathrm{Bax} / \Delta \mathrm{Ct} \mathrm{Bcl}-2(\mathrm{r}=0.477, p=0.03)$ and

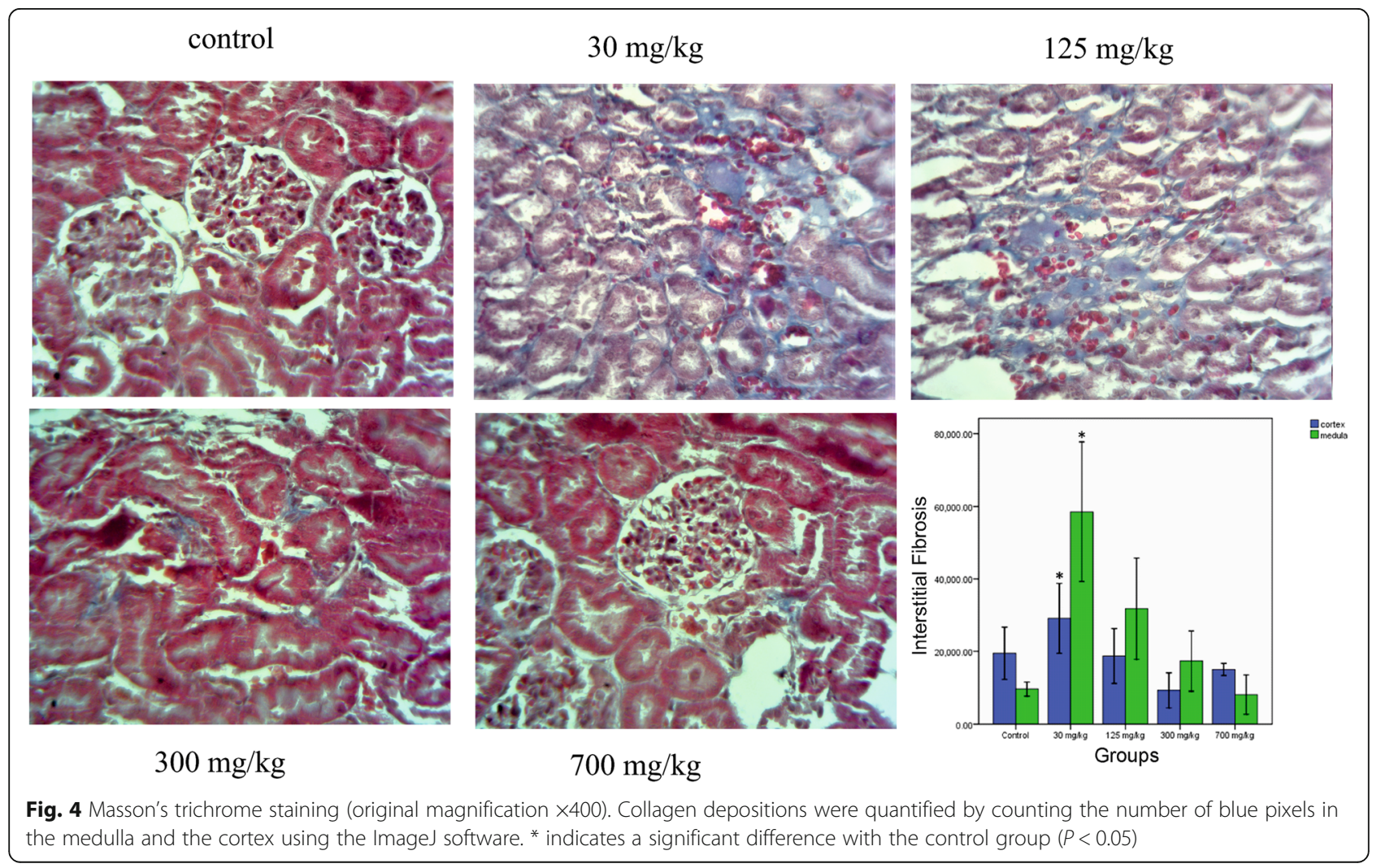



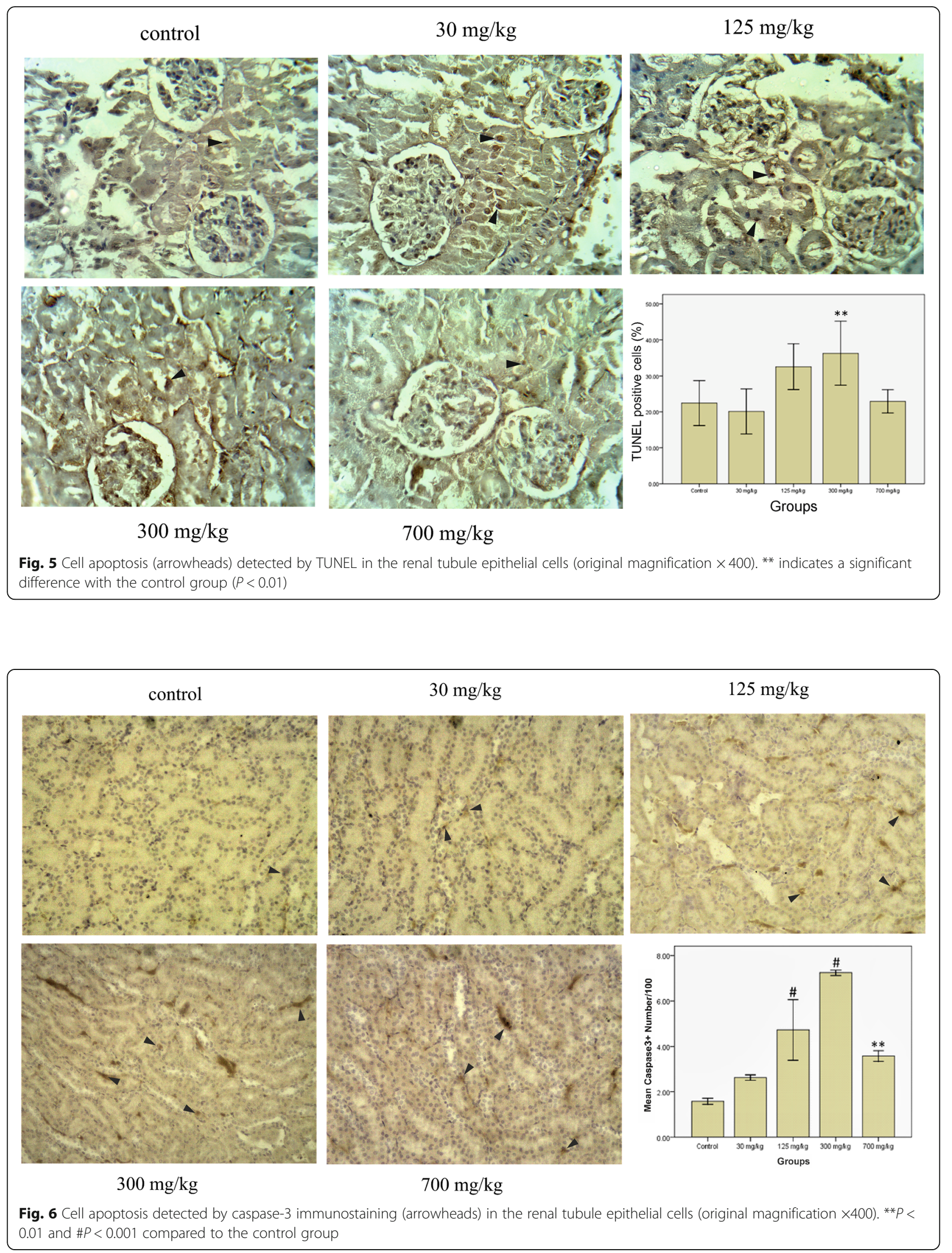

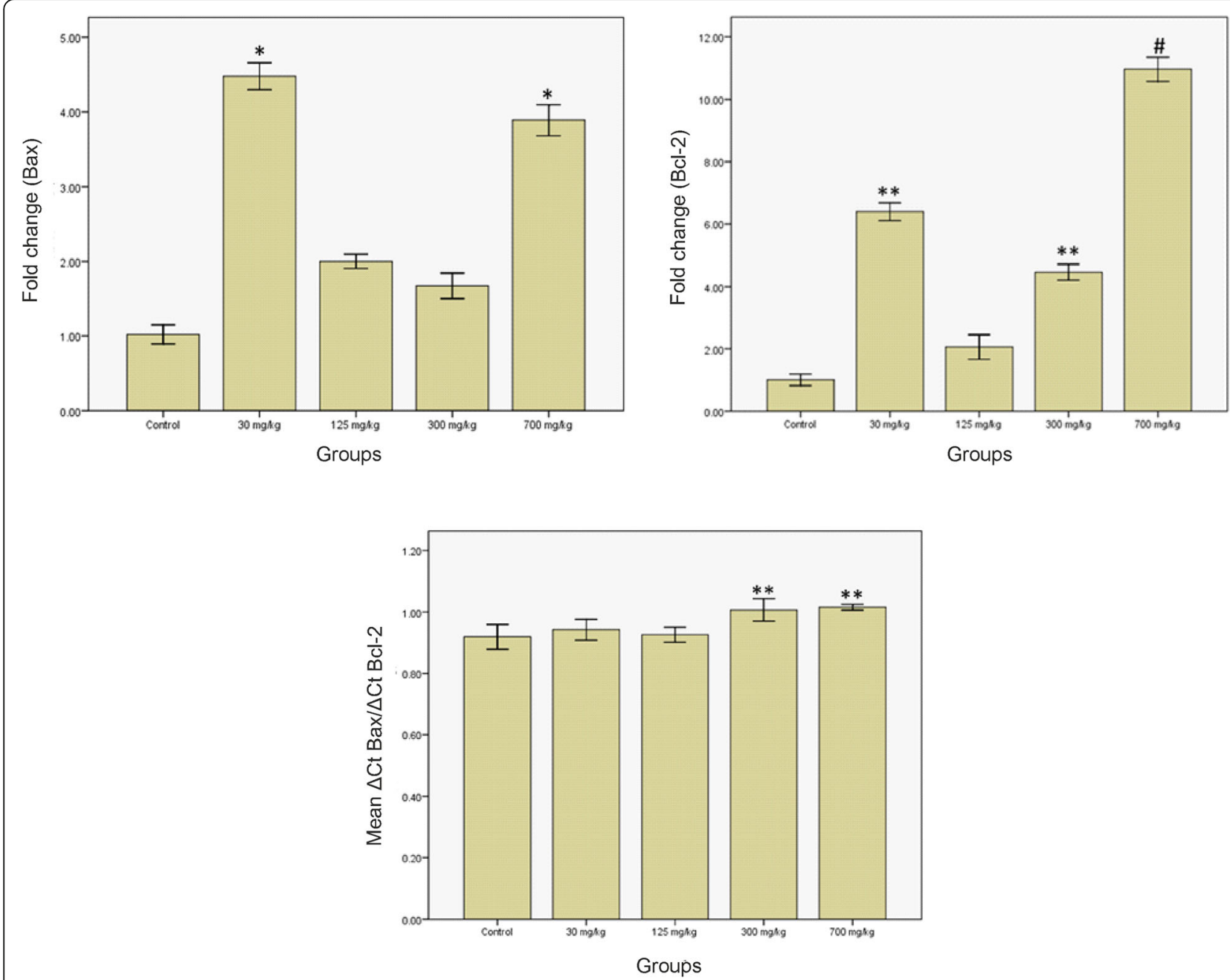

Fig. $7 \mathrm{Bax}$ and $\mathrm{BCl}-2$ genes expression and the ratio of Bax to $\mathrm{BCl}-2$ changes in the kidney of the rats treated with AgNPs. ${ }^{*} P<0.05$, ${ }^{* *} P<0.01$, and $\# P<0.001$ compared to the control group

TUNEL-positive cells $(\mathrm{r}=0.547, p=0.01)$. The correlations between TGF- $\beta 1$, TNF- $\alpha$, and EGF mRNA expression and transcription levels of Bax and Bcl-2 are shown in Table 3.

\section{Discussion}

Even though AgNPs have numerous advantages that make them ideal for novel biomedical applications, their toxicity has recently become a subject of research [5]. In this regard, in vitro studies have revealed nanosilverrelated toxic effects in rat neuronal cells and hepatocytes, murine stem cells, and human lung epithelial cells $[21,22]$.

Exposure to AgNPs can occur in different ways, including dermal contact, inhalation, and ingestion [23, 24]. The oral route, as an exposure route for AgNPs, may be important in many industries, and in food and medicine products. The daily amount of silver derived from natural sources in food and water ingested by humans is approximately $0.5-30 \mu \mathrm{g}$ [25]. Exposure to AgNPs leads to the translocation of particles to the blood, and their distribution throughout various organs, particularly the kidneys, liver, spleen, brain, and lungs [26]. Kidneys are known as one of the most vulnerable organs after prolonged exposure to nanoparticles [9]. Kim et al. showed that AgNPs accumulated in the kidney after oral administration for 28-90 days [9]. Moreover, the deposition of nanoparticles and silver can occur along the mesangium and glomerular basement membrane $[27,28]$. That is why the present study was conducted to study the adverse effects of AgNPs on rat kidney treated with repeated oral administration for 28 days by examining the bodyweight, the reno-somatic index, serum creatinine and blood urea nitrogen levels, histological changes, and changes in the expression of apoptosis-associated genes and growth factors genes.

The results demonstrated that there were no significant dose-related changes in the bodyweight gains of the 

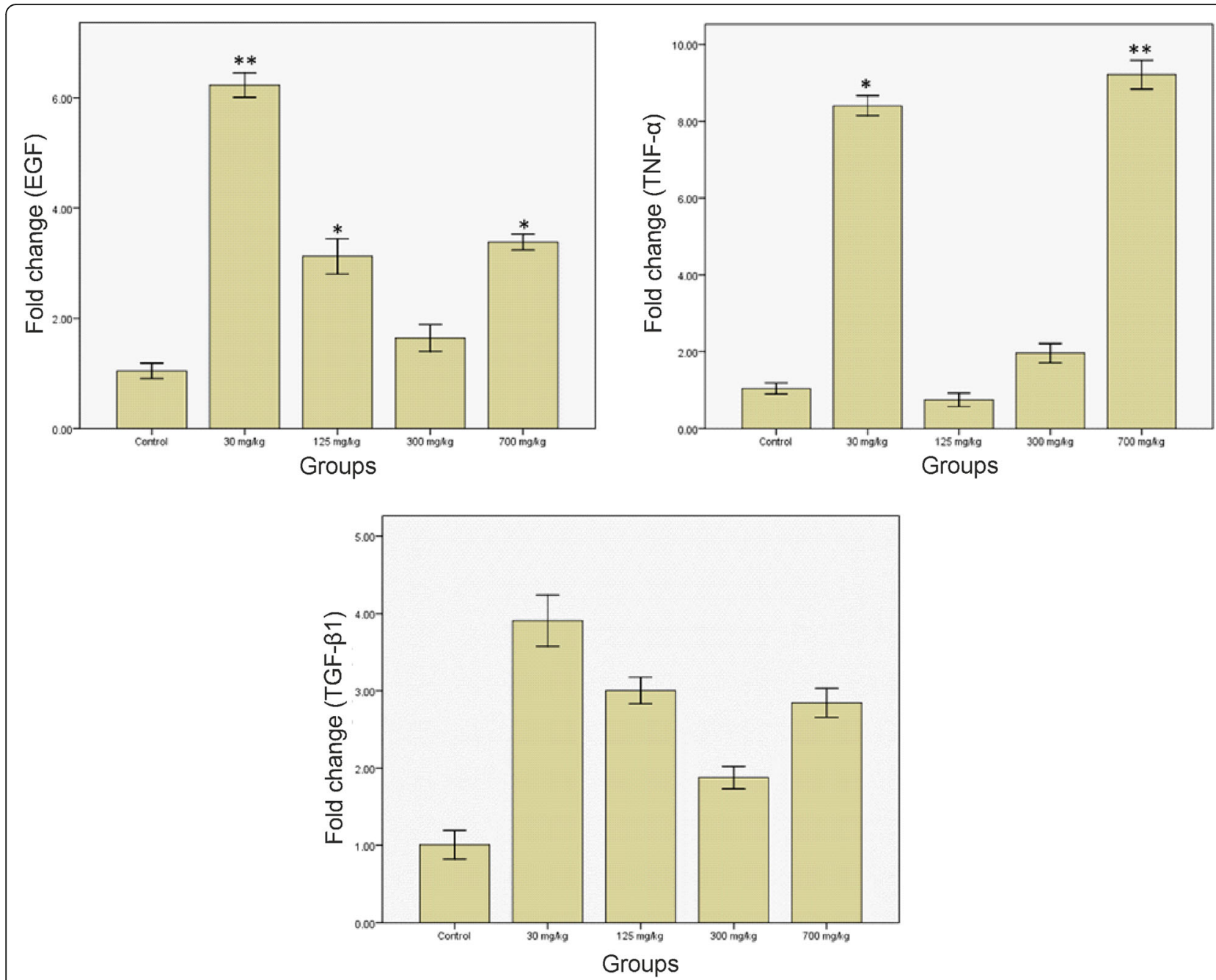

Fig. 8 Gene expression of EGF, TNF- $a$, and TGF- $\beta 1 .{ }^{*} P<0.05$ and ${ }^{*} P<0.01$ compared to the control group

rats. No significant changes in the reno-somatic index were observed in the treated rats. These results are in line with those of Kim [9] and Ji [7], showing no significant changes in bodyweight and renal index due to various concentrations of AgNPs during the 28-day experiment through oral and inhalation exposure.

BUN and creatinine did not increase significantly compared to the control group; however, inflammatory responses were observed in the kidney. It seemed that the inflammatory responses were too week to impair the filtration capacity of the kidney. Using different doses and

Table 3 The correlation between apoptosis-related genes and the expression of growth factors in rats treated with AgNPs

\begin{tabular}{|c|c|c|}
\hline & $\Delta \mathrm{Ct}$ Bax & $\Delta \mathrm{Ct} \mathrm{Bcl-2}$ \\
\hline$\Delta C t$ TGF- $\beta 1$ & $r=0.802(p=0.001)$ & $r=0.636(p=0.003)$ \\
\hline$\Delta C t$ TNF-a & $r=0.610(p=0.006)$ & $r=0.749(p=0.001)$ \\
\hline$\Delta \mathrm{Ct}$ EGF & $r=0.895(p=0.001)$ & $r=0.674(p=0.002)$ \\
\hline
\end{tabular}

durations, other studies have also shown the same results $[9,26,29]$.

The histopathological examination of the kidney shows that dose-dependent AgNPs induced lesions in renal corpuscles, tubules, and interstitial tissues, and inflammation. Partial to complete damages to a number of renal corpuscles with loss of glomerular capillary tufts were observed. The morphometry studies confirmed this result by revealing a significant decrease in the diameter of the affected renal corpuscles compared to the control. However, these changes were more prominent in the groups treated with 30 and $125 \mathrm{mg} / \mathrm{kg}$. Marked glomerular capillary-tuft distortion or complete loss have been described in case of severe renal injury and toxic conditions [30-32].

The results related to the histology of the lining tubular epithelial cells showed damage, including vacuolization, cloudy swelling, severe necrosis, pyknotic nuclei, and degenerative changes, together with desquamation 
of degenerated cells and shedding in the lumen of the tubules. Complete or partial loss of brush border, interrupted basal laminae, and tubular dilatation with intraluminal dense acidophilic hyaline casts were also evident. The results of this study showed that these changes were more frequent in the groups treated with 30 and $125 \mathrm{mg} / \mathrm{kg}$, indicating toxicity induction by these doses. In confirmation of the effects of toxic substances on vacuolar degeneration and cloudy swelling, the evaluations of the effects of cisplatin and different kinds of nanoparticles have shown the same results [33-35]. Almost all observed cytoplasmic and nuclear degenerative changes were more evident in proximal tubules than in distal tubules. This can be because the main primary site of reabsorption and active transmission is the proximal tubules [36].

The hyaline casts represent injured tubular epithelium. The hyaline casts form cellular debris that has undergone molecular changes. Cells and their debris, which is detached from the tubular basement membrane, interact with proteins in the tubular lumen, leading to cast formation. In addition, impaired sodium reabsorption due to the damaged tubular epithelium results in increased sodium concentration in the lumen of tubules, causing protein polymerization and contributing to cast formation [37].

Regarding vascular alterations, consistent with our results, other studies have reported that different nanoparticles with different sizes resulted in expanded and congested renal tubular capillaries with inflammatory infiltration [29, 32]. It has been reported that cell infiltration is a sign of atrophy of tubular cells in chronic kidney diseases [38]. This inflammatory response seems to be a result of the oxidative stress caused by AgNPs, contributing to vascular congestion.

Interstitial tissue fibrosis involves the excessive accumulation of collagen fibrils, and it is a common feature of many diseases that progress to chronic renal failure [39]. Results of this study revealed marked deposition of collagen within the glomeruli and between renal tubules in the groups treated with 30 and $125 \mathrm{mg} / \mathrm{kg}$ compared to other groups. In the formation of renal interstitial fibrosis, a variety of inflammatory cells and growth factors, such as TGF- $\beta 1$, participate. TGF- $\beta 1$ is considered a key mediator of renal interstitial fibrosis [40]. In our study, the expression of TGF- $\beta 1$ increased in groups treated with 30 and $125 \mathrm{mg} / \mathrm{kg}$ of AgNPs to almost 3.98 and 3 times that of the control group, respectively. Moreover, the mean area percent of collagen fibers in the group treated with $30 \mathrm{mg} / \mathrm{kg}$ was significantly higher than that of the control.

In the present study, it seems that the more severe histological changes in rats receiving 30 and $125 \mathrm{mg} / \mathrm{kg}$ and the slight damage in groups receiving 300 and 700 $\mathrm{mg} / \mathrm{kg}$ might be due to the translocation of AgNPs into the kidney. This may be due to the agglomeration of AgNPs used in this study ( 250-nm hydrodynamic diameter agglomerates). The small intestine is the first site for the nanoparticles to be absorbed following oral administration. The agglomeration of AgNPs in high concentrations may have also hindered their intestinal absorption, resulting in an insufficient amount of AgNPs being available to the kidney. Kim et al. reported similar results [9].

The number of renal cells during the development and progression of renal disorders is regulated by apoptosis [41]. Through studying the gene expression of apoptotic regulatory and effector molecules in rats treated with different doses of AgNPs, we obtained a greater understanding of controlling apoptosis in the affected kidney.

$\mathrm{Bcl}-2$ is an apoptosis inhibitory factor, while Bax promotes the process of apoptosis in various tissues, and the state of cell apoptosis is determined by the ratio of their levels of expression [42]. We examined whether the increased ratio of these genes was related to the process of apoptosis in the renal tissue of the rats treated with AgNPs. It was found that the number of caspase-3 positive cells significantly increased in the interstitial and tubular epithelial cells of the rats treated with 125 and $300 \mathrm{mg} / \mathrm{kg}$. Furthermore, the ratio of Bax/Bcl-2 mRNA was correlated with caspase- 3 positive cells. The findings indicate a possible implication of Bax and Bcl-2 in the apoptotic process during AgNPs treatment.

TUNEL, caspase-3, and Bax/Bcl-2 mRNA evaluation showed a lower rate of apoptosis in the group receiving $30 \mathrm{mg} / \mathrm{kg}$ compared to the other tested groups. Given the lack of association between apoptosis (caspase-3 positive cells) and fibrosis or glomerular and tubal injury, alternative non-apoptotic pathways may be activated in this group as more prominent necrosis was found in the group receiving $30 \mathrm{mg} / \mathrm{kg}$.

Activated immune cells produce TNF- $\alpha$ and other pro-inflammatory cytokines in chronic renal disorders, stimulating the release of chemo-attractive molecules by the tubular epithelial cells [43]. It also recruits leukocytes to tubulointerstitium, increasing inflammation, tubulointerstitial damage, and renal dysfunction. Similarly, the results of our study showed that infiltrated immune cells increased in parallel to the increase in the expression of TNF- $\alpha$ mRNAs in the groups receiving 30 and $700 \mathrm{mg} / \mathrm{kg}$. Unlike the group receiving $700 \mathrm{mg} / \mathrm{kg}$, tubulointerstitial damage was observed in the group treated with $30 \mathrm{mg} / \mathrm{kg}$. It seems that the upregulation of TNF- $\alpha$ in the group treated with $700 \mathrm{mg} / \mathrm{kg}$ was because of increased infiltrated leukocytes, which indicate the early stage of renal injury. This inflammatory response is because of the oxidative stress caused by AgNPs, resulting in vascular congestion. 
The positive association between the expression of TGF- $\beta 1$ and the severity of the tubulointerstitial injury and renal dysfunction has been reported in various studies. In these studies, the upregulation of TGF- $\beta 1$ is correlated with an increased risk of progression from chronic renal disease to end-stage renal failure [17, 44].

It has been shown that TGF- $\beta 1$ contributes to tubulointerstitial damage and renal dysfunction through the loss of tubular epithelial cells by inducing apoptosis and increasing fibrosis. Similarly, our results showed more prominent histological changes in the groups receiving 30 and $125 \mathrm{mg} / \mathrm{kg}$ than the group receiving $300 \mathrm{mg} / \mathrm{kg}$.

Our findings revealed an increase in TGF- $\beta 1$, TNF- $\alpha$, and EGF mRNA in some treated groups compared to controls; however, they failed to show any statisticallysignificant correlation between these values and caspase3 or TUNEL-positive cells.

A study by Gobe et al. has shown that the expression of EGF and Bcl-2 in distal tubules increases in the ischemic kidney, leading to distal tubule stress resistance [45]. On the other hand, according to the significant increase in Bcl-2 in the group receiving $300 \mathrm{mg} / \mathrm{kg}$ compared to the other groups, the decreased expression of EGF seems to have led to an increase in apoptosis.

\section{Conclusions}

The present study demonstrated that AgNPs induced renal toxicity at both morphological and molecular levels after repeated oral administration. We conclude that renal fibrosis is associated with progressive tubular and glomerular changes in the experimental groups. Furthermore, the ratio of $\mathrm{Bax} / \mathrm{Bcl}-2$ mRNA was correlated with caspase- 3 positive cells. The findings indicate a possible implication of $\mathrm{Bax}$ and $\mathrm{Bcl}-2$ in the apoptotic process during AgNPs treatment. The transcription levels of TGF- $\beta 1$, TNF- $\alpha$, and EGF are correlated with Bax and Bcl-2 mRNA expression, indicating that these growth factors might be involved in the regulation of apoptosis.

\section{Abbreviations}

AgNPs: Silver nanoparticles; BUN: Blood urea nitrogen; Ct: Cycle threshold; DLS: Dynamic light scattering; EGF: Epidermal growth factor; H\&E: Hematoxylin and eosin; HRP: Horseradish peroxidase; PAS: Periodic acidSchiff; RT-PCR: Reverse transcription polymerase chain reaction; TGF$\beta 1$ : Transforming growth factor $\beta 1$; TNF-a: Tumour necrosis factor $\alpha$; TUNEL: Terminal deoxynucleotidyl transferase dUTP nick end labeling

\section{Acknowledgements}

Not applicable.

\section{Authors' contributions}

$\mathrm{HN}, \mathrm{MH}$, and NS performed the histological and molecular examinations and were contributors in writing the manuscript. ZG treated the animals. ZA, MSo, MSa, and MA designed the study, analyzed and interpreted the data, and were major contributors in writing the paper. All authors read and approved the final manuscript.

\section{Funding}

This study was funded by Vice-chancellor for Research and Technology, Hamadan University of Medical Sciences, Hamadan, Iran (No. 9311145896).

\section{Availability of data and materials}

All data generated or analyzed during this study are included in this published article.

\section{Declarations}

\section{Ethics approval and consent to participate}

The above-mentioned treatment/sampling protocols were approved by the Ethics Committee of Hamadan University of Medical Sciences (ethical code: IR.UMSHA.REC.1394.553). Moreover, all the methods were carried out in accordance with the relevant guidelines and regulations. The study was carried out in compliance with the ARRIVE guidelines.

\section{Consent for publication}

Not applicable.

\section{Competing interests}

The authors declare that they have no competing interests.

\section{Author details}

${ }^{1}$ Department of Anatomical Sciences, School of Medicine, Hamadan University of Medical Sciences, Hamadan, Iran. ${ }^{2}$ Research Center for Molecular Medicine, Hamadan University of Medical Sciences, Hamadan, Iran. ${ }^{3}$ Research Center for Health Sciences, School of Public Health, Hamadan University of Medical Sciences, Hamadan, Iran. ${ }^{4}$ Endometrium and Endometriosis Research Center, Hamadan University of Medical Sciences, Hamadan, Iran. ${ }^{5}$ Department of Anatomical Sciences, Hamadan University of Medical Sciences, Shahid Fahmideh Ave., P.O. Box. 65178-518, Hamadan, Iran.

Received: 26 December 2020 Accepted: 28 May 2021

Published online: 18 June 2021

\section{References}

1. Hill EK, Li J. Current and future prospects for nanotechnology in animal production. J Anim Sci Biotechnol. 2017:8(1):26.

2. Nosrati H, Aramideh Khouy R, Nosrati A, Khodaei M, Banitalebi-Dehkordi M, Ashrafi-Dehkordi K, et al. Nanocomposite scaffolds for accelerating chronic wound healing by enhancing angiogenesis. J Nanobiotechnol. 2021;19(1):1.

3. Zhang X-F, Liu Z-G, Shen W, Gurunathan S. Silver nanoparticles: synthesis, characterization, properties, applications, and therapeutic approaches. Int J Mol Sci. 2016;17(9):1534.

4. Vance ME, Kuiken T, Vejerano EP, McGinnis SP, Hochella MF Jr, Rejeski D, et al. Nanotechnology in the real world: redeveloping the nanomaterial consumer products inventory. Beilstein J Nanotechnol. 2015;6(1):1769-80.

5. Burdușel AC, Gherasim O, Grumezescu AM, Mogoantă L, Ficai A, Andronescu E. Biomedical applications of silver nanoparticles: an up-to-date overview. Nanomaterials (Basel, Switzerland). 2018;8(9):681.

6. Bergin IL, Witzmann FA. Nanoparticle toxicity by the gastrointestinal route: evidence and knowledge gaps. Int J Biomed Nanosci Nanotechnol. 2013; 3(1-2):163-210.

7. Ji JH, Jung JH, Kim SS, Yoon J-U, Park JD, Choi BS, et al. Twenty-eight-day inhalation toxicity study of silver nanoparticles in Sprague-Dawley rats. Inhal Toxicol. 2007;19(10):857-71.

8. Crosera M, Bovenzi M, Maina G, Adami G, Zanette C, Florio C, et al. Nanoparticle dermal absorption and toxicity: a review of the literature. Int Arch Occup Environ Health. 2009;82(9):1043-55.

9. Kim YS, Kim JS, Cho HS, Rha DS, Kim JM, Park JD, et al. Twenty-eight-day oral toxicity, genotoxicity, and gender-related tissue distribution of silver nanoparticles in Sprague-Dawley rats. Inhal Toxicol. 2008;20(6):575-83.

10. Sambale F, Wagner S, Stahl F, Khaydarov RR, Scheper T, Bahnemann D. Investigations of the toxic effect of silver nanoparticles on mammalian cell lines. J Nanomater. 2015;16(1):6.

11. Mahmoudian ZG, Sohrabi M, Lahoutian H, Assari MJ, Alizadeh Z. Histological alterations and apoptosis in rat liver following silver nanoparticle intraorally administration. Entomol Appl Sci Lett. 2016;3(5):27-35.

12. Chairuangkitti $P$, Lawanprasert $S$, Roytrakul $S$, Aueviriyavit $S$, Phummiratch $D$, Kulthong $\mathrm{K}$, et al. Silver nanoparticles induce toxicity in A549 cells via ROS- 
dependent and ROS-independent pathways. Toxicol in Vitro. 2013;27(1): 330-8.

13. Kim S, Choi JE, Choi J, Chung K-H, Park K, Yi J, et al. Oxidative stressdependent toxicity of silver nanoparticles in human hepatoma cells. Toxicol in Vitro. 2009;23(6):1076-84

14. Schelling JR. Tubular atrophy in the pathogenesis of chronic kidney disease progression. Pediatr Nephrol. 2016;31(5):693-706.

15. Mooney A, Jobson T, Bacon R, Kitamura M, Savill J. Cytokines promote glomerular mesangial cell survival in vitro by stimulus-dependent inhibition of apoptosis. J Immunol. 1997;159(8):3949-60.

16. Ortiz A, Lorz C, Catalán MP, Danoff TM, Yamasaki Y, Egido J, et al. Expression of apoptosis regulatory proteins in tubular epithelium stressed in culture or following acute renal failure. Kidney Int. 2000;57(3):969-81.

17. Teteris SA, Menahem S, Perry G, Maguire JA, Dowling J, Langham RG, et al. Dysregulated growth factor gene expression is associated with tubulointerstitial apoptosis and renal dysfunction. Kidney Int. 2007;71(10): 1044-53.

18. Ding G, Reddy K, Kapasi AA, Franki N, Gibbons N, Kasinath BS, et al. Angiotensin II induces apoptosis in rat glomerular epithelial cells. Am J Physiol Renal Physiol. 2002;283(1):F173-F80.

19. Pourhamzeh M, Mahmoudian ZG, Saidijam M, Asari MJ, Alizadeh Z. The effect of silver nanoparticles on the biochemical parameters of liver function in serum, and the expression of caspase-3 in the liver tissues of male rats. Avicenna J Med Biochem. 2016;4(2):7.

20. Livak KJ, Schmittgen TD. Analysis of relative gene expression data using real-time quantitative PCR and the $2-\Delta \Delta C T$ method. Methods. 2001;25(4): 402-8.

21. Pinzaru I, Coricovac D, Dehelean C, Moacă E-A, Mioc M, Baderca F, et al. Stable PEG-coated silver nanoparticles-a comprehensive toxicological profile. Food Chem Toxicol. 2018;111:546-56

22. El Mahdy MM, Eldin TAS, Aly HS, Mohammed FF, Shaalan MI. Evaluation of hepatotoxic and genotoxic potential of silver nanoparticles in albino rats. Exp Toxicol Pathol. 2015;67(1):21-9.

23. Kim W-Y, Kim J, Park JD, Ryu HY, Yu IJ. Histological study of gender differences in accumulation of silver nanoparticles in kidneys of Fischer 344 rats. J Toxicol Environ Health A. 2009:72(21-22):1279-84.

24. Pronk M, Wijnhoven SW, Bleeker E, Heugens EH, Peijnenburg WJ, Luttik R, et al. Nanomaterials under REACH. Nanosilver as a case study; 2009.

25. Hadrup N, Lam HR. Oral toxicity of silver ions, silver nanoparticles and colloidal silver-a review. Regul Toxicol Pharmacol. 2014:68(1):1-7.

26. Yang L, Kuang H, Zhang W, Aguilar ZP, Wei H, Xu H. Comparisons of the biodistribution and toxicological examinations after repeated intravenous administration of silver and gold nanoparticles in mice. Sci Rep. 2017;7(1): 3303.

27. Zuckerman JE, Gale A, Wu P, Ma R, Davis ME. siRNA delivery to the glomerular mesangium using polycationic cyclodextrin nanoparticles containing siRNA. Nucleic Acid Therap. 2015;25(2):53-64.

28. Day W, Hunt J, McGiven A. Silver deposition in mouse glomeruli. Pathology. 1976:8(3):201-4

29. Park E-J, Bae E, Yi J, Kim Y, Choi K, Lee SH, et al. Repeated-dose toxicity and inflammatory responses in mice by oral administration of silver nanoparticles. Environ Toxicol Pharmacol. 2010;30(2):162-8.

30. Scott K, Webb M, Sorrentino SA. Long-term caring-e-Book: Residential, home and community aged care. Amsterdam: Elsevier Health Sciences; 2015.

31. Awadalla EA, Salah-Eldin A-E. Histopathological and molecular studies on tramadol mediated hepato-renal toxicity in rats. J Pharm Biol Sci. 2015;10(6): 90-102.

32. Ibrahim K, Al-Mutary M, Bakhiet A, Khan H. Histopathology of the liver, kidney, and spleen of mice exposed to gold nanoparticles. Molecules. 2018; 23(8):1848.

33. Ma P, Luo Q, Chen J, Gan Y, Du J, Ding S, et al. Intraperitoneal injection of magnetic $\mathrm{Fe}_{3} \mathrm{O}_{4}$-nanoparticle induces hepatic and renal tissue injury via oxidative stress in mice. Int J Nanomedicine. 2012;7:4809.

34. Abdelhalim MAK, Jarrar BM. Renal tissue alterations were size-dependent with smaller ones induced more effects and related with time exposure of gold nanoparticles. Lipids Health Dis. 2011;10(1):163.

35. Sahu BD, Kuncha M, Sindhura GJ, Sistla R. Hesperidin attenuates cisplatininduced acute renal injury by decreasing oxidative stress, inflammation and DNA damage. Phytomedicine. 2013;20(5):453-60.
36. Curthoys NP, Moe OW. Proximal tubule function and response to acidosis. Clin J Am Soc Nephrol. 2014:9(9):1627-38.

37. Abuelo JG. Normotensive ischemic acute renal failure. N Engl J Med. 2007; 357(8):797-805.

38. Sadek EM, Salama NM, Ismail DI, Elshafei AA. Histological study on the protective effect of endogenous stem-cell mobilization in Adriamycininduced chronic nephropathy in rats. J Microsc Ultrastruct. 2016;4(3):133-42.

39. Bedi S, Vidyasagar A, Djamali A. Epithelial-to-mesenchymal transition and chronic allograft tubulointerstitial fibrosis. Transplant Rev. 2008;22(1):1-5.

40. Farris $A B$, Colvin RB. Renal interstitial fibrosis: mechanisms and evaluation. Curr Opin Nephrol Hypertens. 2012;21(3):289.

41. Havasi A, Borkan SC. Apoptosis and acute kidney injury. Kidney Int. 2011; 80(1):29-40

42. Yang B, Johnson TS, Thomas GL, Watson PF, Wagner B, Skill NJ, et al. Expression of apoptosis-related genes and proteins in experimental chronic renal scarring. J Am Soc Nephrol. 2001;12(2):275-88.

43. Kuroiwa T, Schlimgen R, Illei GG, McInnes IB, Boumpas DT. Distinct T cell/ renal tubular epithelial cell interactions define differential chemokine production: implications for tubulointerstitial injury in chronic glomerulonephritides. J Immunol. 2000;164(6):3323-9.

44. August $\mathrm{P}$, Suthanthiran $\mathrm{M}$. Transforming growth factor beta and progression of renal disease: management of comorbidities in kidney disease in the 21st century: anemia and bone disease. Kidney Int. 2003;64:S99-S104.

45. Gobe G, Zhang X-J, Willgoss DA, Schoch E, Hogg NA, Endre ZH. Relationship between expression of $\mathrm{BCl}-2$ genes and growth factors in ischemic acute renal failure in the rat. J Am Soc Nephrol. 2000;11(3):454-67.

\section{Publisher's Note}

Springer Nature remains neutral with regard to jurisdictional claims in published maps and institutional affiliations.

Ready to submit your research? Choose BMC and benefit from:

- fast, convenient online submission

- thorough peer review by experienced researchers in your field

- rapid publication on acceptance

- support for research data, including large and complex data types

- gold Open Access which fosters wider collaboration and increased citations

- maximum visibility for your research: over $100 \mathrm{M}$ website views per year

At $\mathrm{BMC}$, research is always in progress.

Learn more biomedcentral.com/submissions 